\title{
Treatment of colorectal liver metastases
}

\author{
Nabil Ismaili
}

\begin{abstract}
Colorectal cancer (CRC) is the third most common cancer in the word. Liver metastasis is the most common site of colorectal metastases. The prognosis of resectable colorectal liver metastases (CRLM) was improved in the recent years with the consideration of chemotherapy and surgical resection as part of the multidisciplinary management of the disease; the current 5-year survival rates after resection of liver metastases are $25 \%$ to $40 \%$. Resectable synchronous or metachronous liver metastases should be treated with perioperative chemotherapy based on three months of FOLFOX4 (5-fluorouracil [5FU], folinic acid [LV], and oxaliplatin) chemotherapy before surgery and three months after surgery. In the case of primary surgery, pseudo-adjuvant chemotherapy for 6 months, based on 5FU/LV, FOLFOX4, XELOX (capecitabine and oxaliplatin) or FOLFIRI (5FU/LV and irinotecan), should be indicated. In potentially resectable disease, primary chemotherapy based on more intensive regimens such as FOLFIRINOX (5FU/LV, irinotecan and oxaliplatin) should be considered to enhance the chance of cure. The palliative chemotherapy based on FOLFIRI, or FOLFOX4/XELOX with or without targeted therapies, is the mainstay treatment of unresectable disease. This review would provide additional insight into the problem of optimal integration of chemotherapy and surgery in the management of CRLM.
\end{abstract}

\section{Background}

Colorectal cancer (CRC) is the third most commonly diagnosed cancer in males and the second in females. It is the second most deathly cancer worldwide. About 1.2 million new cases and 608,700 deaths were reported to have occurred in 2008. However, the mortality rates have been decreasing dramatically in western countries largely resulting from improved treatment and increased awareness and early detection [1].

Liver is the most common site of metastasis from colorectal cancers (50-60\% of the cases). Close to one third of patients have liver metastases either at the time of diagnosis (synchronous in $1 / 3$ of the cases) or during the disease course (metachronous in $2 / 3$ of the cases).

The prognosis of colorectal liver metastases (CRLM) has improved in the last few years. Surgical resection of liver metastases is considered the only curative treatment option for patients with resectable liver metastases and no extrahepatic disease [2,3]. Five years survival has increased from $<8 \%$, using palliative chemotherapy (CT), to $25-40 \%$ using multimodal management including CT and surgery $[1,2,4-7]$

\footnotetext{
Correspondence: ismailinabil@yahoo.fr

Correspondence: ismailinabil@yahoo.fr
Department of medical oncology, Regional cancer center, Hassan II Hospital, Agadir-80000, Morocco
}

Liver metastases are resectable in only $15 \%$ of the cases. Eighty five percents of the patients are ineligible to surgery because of the location, the size, the number of liver metastases, the residual normal liver, and the extra hepatic disease $[2,8]$. After primary surgery, the rate of relapse is high. This has led the investigators to evaluate the role of neoadjuvant and adjuvant $\mathrm{CT}$ in the management of these patients [9]. Furthermore, neoadjuvant CT is being increasingly used to downsize CRLM and render $10 \%$ to $30 \%$ of initially unresectable patients potentially resectable $[8,10]$. Local hepatic arterial infusion (HAI) CT after liver resection has proved to be effective; however, this technique is not widely used, because of concern of complications and the technical difficulties [11-13].

In general, the term neoadjuvant is used when the CT treatment is given preoperatively, adjuvant when the CT treatment is given postoperatively, and perioperative when the CT treatment is given both before and after surgery.

Limited data analyzed the role of targeted therapies (Bevacizumab and Cetuximab) in preoperative setting. The predictor factors such as K-RAS are crucial before the indication of optimal targeted therapy.
C Bïomed Central 
The present paper aimed to review the current data evaluating the role of preoperative, adjuvant, and perioperative CT in the management of CRLM.

\section{Strategies of literature research}

The present review was based on a systematic literature search of Medline (Pubmed), last accessed 21 August 2011. The abstracts of papers presented at the annual meetings of the American Society of Medical Oncology (ASCO) were also analyzed. The key words used were: colorectal cancer, liver metastases, chemotherapy, targeted therapies, neoadjuvant, perioperative, adjuvant, steatohepatitis, and sinusoidal obstruction. All phases III and metanalyses are included. Selected phases II studies are also analyzed. Studies assessing local HAICT are excluded.

\section{Standard chemotherapy in metastatic setting}

Prior to 2000, standard treatment for metastatic colorectal cancer was based on palliative CT using single-agent 5FU (or fluoropyrimidine drugs) combined with folinic acid (LV). The response rate with 5FU and folinic acid $(5 \mathrm{FU} / \mathrm{LV})$ is approximately $20 \%$. Initial randomized studies confirmed that regimen based on $5 \mathrm{FU} / \mathrm{LV}$, improved median survival of patients with metastatic disease from 8 to 12 months [14]. Subsequently the combination of $5 \mathrm{FU}$ with oxaliplatin typically FOLFOX or XELOX (capecitabine and oxaliplatin) and irinotecan typically FOLFIRI or XELIRI (capecitabine and irinotecan), has yielded overall response rate (ORR) of between $20-30 \%$ to $40-50 \%$, and median overall survival (OS) of between 12 to 20 months [15-18].

The optimal sequencing of these two standard CT (FOLFOX or FOLFIRI) was evaluated by Tournigand and collaborators. They confirmed the survival equivalence of the two therapeutic sequences: FOLFOX first then FOLFIRI or FOLFIRI first then FOLFOX. However, the FOLFOX first was associated with a higher complete response rates (CRR) than FOLFIRI (4.5 vs. $2.8 \%$ ). In addition, in the FOLFOX arm, $22 \%$ of patients received surgery for liver metastases vs. $9 \%$ in FOLFIRI arm ( $\mathrm{p}=$ 0.02 ), leading to the usual use of FOLFOX CT in neoadjuvant setting. Toxicity profile of these 2 standard regimens was different. Grade 3/4 mucositis, nausea/ vomiting, and grade 2 alopecia were more frequent with FOLFIRI, and grade $3 / 4$ neutropenia and neurosensory toxicity were more frequent with FOLFOX [19].

A pooled analysis of seven randomized studies showed that survival is enhanced by the administration of all the three active agents, irrespective of their sequence. An interesting finding of this last analysis is that only 50 $80 \%$ of patients are suitable for a second line CT and ultimately received the three drugs [20]. In the attempt to enhance treatment results and to increase the proportion of patients exposed to all active agents, a combined administration of $5 \mathrm{FU} / \mathrm{LV}$, irinotecan and oxaliplatin (FOLFIRINOX) has been developed. The FOLFIRINOX was evaluated in first line in comparison with the standard FOLFIRI, in 2 randomized phase III studies $[21,22]$. In a well designed study, FOLFIRINOX showed to be more effective (in ORR, progression free survival [PFS] and OS) than FOLFIRI and was associated with a higher secondary resection rate of liver metastases $(36 \%$ vs. $12 \% ; \mathrm{p}=0.017)$. This regimen was particularly toxic (grade $3 / 4$ neutropenia $=50 \%$ vs. $28 \%$ ) and requires special precautions [21]. The pooled analyses of theses 2 randomized studies confirmed these positives results [23]. FOLFIRINOX is an interesting regimen particularly in neoadjuvant setting for the management of potentially resectables CRLM.

The progress in molecular biology has prompted the investigators to develop new molecules targeting specific abnormalities in the cancer cells, with a very acceptable toxicity profile. Additional improvements in outcome have been associated with the use of biological agents in combination with cytotoxic CT. Two molecules are currently included in the first line treatment of metastatic CRC [24-29]. Bevacizumab is a humanized monoclonal antibody targeting the most important factor implicated in tumor angiogenesis called vascular endothelial growth factor (VEGF), and was the first molecule developed in the treatment of metastatic CRC. In first line, it was evaluated in randomized phase III trials in combination with IFL (5FU/LV bolus and irinotecan), FOLFIRI, FOLFOX, and XELOX. These studies confirmed the benefit of bavacizumab in ORR, PFS, and OS (table 1) [24-26]. Cetiximab is a chimeric monoclonal antibody targeting the epidermal growth factor receptor (EGFR). Two randomized trials in metastatic setting showed that adding cetuximab to FOLFIRI or FOLFOX, improved outcomes (ORR and PFS) in patients with K-RAS wild type tumors (table 2) $[28,29]$. With the use of bevacizumab and cetuximab in combination with $\mathrm{CT}$, survival of patients has improved to more than 24 months.

\section{New staging system}

A new staging system was proposed by the European Colorectal Metastases Treatment Group (ECMTG) that would subdivide the $\mathrm{M}$ from the TNM classification into 4 groups [8]:

"M0: no metastases

"M1a: resectable liver metastases

"M1b: potentially resectable liver metastases

"M1c: liver metastases those are unlikely to ever become resectable.

For both the M1a resectable patients and the M1b patients who become resectable after systemic treatment, resection offers the possibility of cure. For the 
Table 1 Randomized phase III trials evaluating Bevacizumab in combination with chemotherapy in first line treatment of metastatic CRC

\begin{tabular}{lclccc}
\hline Trials in first line treatment & & \multicolumn{2}{c}{ Results } \\
\hline Trial name/Author & No & Treatments & ORR (\%) & $\begin{array}{c}\text { PFS (months) } \\
\text { (first end point) }\end{array}$ & OS (months) \\
\hline Hurwitz (2004) [24] & 813 & IFL \pm Bevacizumab & 45 vs. $35(p=0.004)$ & 10.6 vs. $6.2(p<0.001)$ & 20.3 vs. 15.6 ( $p<0.001)$ \\
\hline BICC-C (2007) [25] & 430 & IFL/FOLFIRI \pm Bevacizumab & 57.9 vs. 53.3 (NS) & 11.2 vs. $8.3(p=0.007)$ & NR vs. 19.2 ( $p=0.007)$ \\
\hline NO 16966 (2008) [26] & 1401 & XELOX/FOLFOX \pm Bevacizumab & 47 vs. 49 (NS) & 9.4 vs. $8(p=0.0023)$ & 21.3 vs. 19.9 ( $p=0.077)$ \\
\hline
\end{tabular}

Abbreviations. ORR: overall response rate; DFS: disease free survival; OS: overall survival

M1c group, the possibility of doing a resection should not be excluded. Resection should be discussed in multidisciplinary team meetings.

\section{Criteria of resectability}

There are at least three categories of patients with CRLM:

-First, the hepatic lesion(s) are clearly resectable at the time of presentation.

-Second, the hepatic lesion(s) are unresectable at presentation but potentially convertible to resection after primary $\mathrm{CT}$ called conversion $\mathrm{CT}$.

-Third, the hepatic lesion(s) are unresectable and are unlikely to become resectable even with effective CT.

Relative contraindications of liver resection are synchronous rectal cancer; multiple, diffuse or large liver metastases; extrahepatic metastases; high level of $\mathrm{ACE}$ (> $200 \mathrm{ng} / \mathrm{ml}$ ). In patients with no evidence of extrahepatic disease, the main contraindications to liver resection are tumors located close to the hepatic veins and inferior vena cava or to the liver hilum, larges, or numerous liver metastases. Contraindication usually results from a combination of these main causes that precludes liver resection with a sufficient margin of $\geq 1 \mathrm{~cm}$. Curative resection is exceptional for patients with more than 4 metastases. These systems were established before the air of modern CT [6,30,31]

(A) French recommendations (FFCD)

The French recommendations divided the resectability on different classes [32,33]:
"Resectability of class I; easily resectable by experienced surgeons in liver surgery:

-Four or less than 4 segments involved and residual healthy liver volume $>40 \%$ :

-Vena cava free from tumor;

$-\leq 1$ hepatic vein,

-Contra-lateral portal pedicule.

"Resectability of class II; potentially resectable metastases by experienced surgeons in liver surgery: 5 to 6 segments involved \pm contra-lateral major named vascular structures within liver. The hepatectomy is possible by a complex or large resection (more than 4 segments) that requires difficult and/or risky procedure (central hepatectomy, extended right hepatectomy, vascular reconstruction).

*Resection is not possible in the case of: (1) involvement of two portals branches; (2) involvement of one portal branch and a contra-lateral hepatic vein: or (3) involvement of three hepatic veins.

Prognostic factors are: Size $>5 \mathrm{~cm}$, number $>4$, bilobar character, invasion of pedicle lymph node, and/or high level of ACE.

\section{(B) Oncosurge system}

The oncosurge system define the respectability as the possibility of resection of all liver metastases with negative margins $>1 \mathrm{~cm}$ and a residual healthy liver volume $>20 \%$. In this system, the prognostic factors are the performance status and the percentage of the underlying healthy liver. The extrahepatic metastases (hilar lymph

Table 2 Randomized phase III trials evaluating Cetuximab in combination with chemotherapy in first line treatment of metastatic CRC

\begin{tabular}{|c|c|c|c|c|c|}
\hline \multicolumn{3}{|c|}{$\begin{array}{l}\text { Trials in first line treatment } \\
\text { (K-RAS wild type) }\end{array}$} & \multicolumn{3}{|c|}{ Results } \\
\hline Trial name/Author & No & Treatments & ORR (\%) & $\begin{array}{l}\text { PFS (months) } \\
\text { (first end point) }\end{array}$ & OS (months) \\
\hline $\begin{array}{l}\text { CRYSTAL (2009) [28] } \\
\text { (phase 3) }\end{array}$ & 599 & FOLFIRI \pm Cetiximab & 59 vs. $43(p=0.03)$ & $\begin{array}{c}9.9 \text { vs. } 8.7 \\
(\mathrm{HR}=0.68 ; 95 \% \mathrm{Cl}, 0.50 \text { to } 0.94)\end{array}$ & 23.5 vs. $20(H R=0.80)$ \\
\hline $\begin{array}{l}\text { OPUS (2009) [29] } \\
\text { (phase 2) }\end{array}$ & 338 & FOLFOX \pm Cetuximab & 61 vs. $37(p=0.01)$ & 8.3 vs. $7.2(H R=0.57 ; p=0.016)$ & 22.8 vs. $18.5(\mathrm{HR}=0.86)$ \\
\hline
\end{tabular}

Abbreviations. ORR: overall response rate; PFS: progression free survival; OS: overall survival 
nodes, lung, ovary, and/or adrenal metastases) are not a formal contraindication against surgery. Currentely approximately $20 \%$ of the patients with liver metastases can be resected, and have an estimated 5 years survival of $50 \%$ [34].

\section{Neoadjuvant chemotherapy}

Neoadjuvant CT should be distinguished from conversion CT, which is also administered in the pre-operative setting but is administered to patients with initially unresectable disease, with the intention of downsizing the tumor burden, and, ultimately, considering resection.

\section{(A) Conversion chemotherapy in initially unresectable} colorectal liver metastases

Only a minority of patients with liver metastases is amenable directly to surgery (15\%). Therefore, efforts have been made to increase the resectability of patients with initially unresectable colorectal liver metastases.

The downsizing of CRLM can have a number of advantages:

(1) small metastases can disappear in one lobe allowing resection of metastases in the opposite lobe;

(2) major vascular pedicles of the liver may become free from tumor;

(3) large lesions may become accessible to ablative techniques, when they shrink to less than $3 \mathrm{~cm}$ in diameter.
The role of conversion CT was evaluated in numerous retrospective and phase II studies [10,19,35-47]. In a large surgical series of 1104 patients with initially unresectable liver metastases, the 5 years survival of the resected patient (12\%) following primary CT was $33 \%$, that approached the 5 years survival rate of the resectable patients in the same period (equal to $48 \%$ ) [10]. In a retrospective French study, 131 patients with unresectable liver metastases were included and received 3- 6 months of CT. In 57 patients (44\%), curative surgery of liver metastases was considered possible. After 39 months median follow-up, the 4 years survival in resected patients was $37 \%$. The rate of postoperative complication was $14 \%$ [35]. In addition, prospective studies confirmed the ability of neoadjuvant $\mathrm{CT}$ to render some metastases resectable. However, there is a wide differences in the liver resection rates reported for theses different trials reflecting in one part the differences in criteria for respectability/ unresectability that exist between the different centers, in the absence of a clear definition. In another part, theses differences can be explained by the CT regimens used; in fact, FOLFOX, and FOLFIRINOX showed to be the most effective protocols (table 3 ) [19,36-47].

(B) Neoadjuvant chemotherapy in resectable colorectal liver metastases

Neoadjuvant CT is the administration of chemotherapy in the pre-operative setting in patients with resectable

Table 3 Published prospective trials evaluating the resectability rate after first line-chemotherapy in patients with initially unresectable colorectal liver metastases

\begin{tabular}{|c|c|c|c|c|c|}
\hline Auto (year) & No & Treatments & ORR & Resectability rate & Perioperative complications \\
\hline Wein (2001) [36] & 53 & $5 F U / L V$ & $41 \%$ & $11 \%$ & Acceptable \\
\hline Pozzo (2002) [37] & 40 & 5FU/LV + irinotecan & $47.5 \%$ & $32.5 \%$ & Acceptable \\
\hline Cals (2004) [38] & 34 & 5FU/LV + irinotecan + oxaliplatin & $50 \%$ & $15 \%$ & Acceptable \\
\hline \multirow[t]{2}{*}{ Tourniguand (2004) [19] } & 109 & FOLFOX & $54 \%$ & $22 \%$ & Acceptable \\
\hline & 111 & FOLFIRI & $56 \%$ & $9 \%$ & Acceptable \\
\hline \multirow[t]{2}{*}{ Kohne (2005) [39] } & 216 & 5FU/LV + irinitecan & $62.2 \%$ & $7 \%$ & Acceptable \\
\hline & 214 & $5 F U / L V$ & $34.4 \%$ & $3 \%$ & Acceptable \\
\hline Ho (2005) [40] & 40 & 5FU/LV/IRI & $55 \%$ & $10 \%$ & Acceptable \\
\hline Seium (2005) [41] & 30 & 5FU/LV + irinotecan + oxaliplatin & $78 \%$ & $23 \%$ & Hematological+++ \\
\hline Alberts (2005) [42] & 42 & FOLFOX & $60 \%$ & $40 \%$ & Acceptable \\
\hline Masi (2006) [43] & 74 & FOLFIRINOX & $72 \%$ & $26 \%$ & \\
\hline Ychou (2007) [44] & 34 & FOLFIRINOX & $70.6 \%$ & $26.5 \%$ & $\begin{array}{c}\text { Acceptable } \\
\text { Hematological+++ }\end{array}$ \\
\hline \multirow[t]{2}{*}{ Falcone (2007) [21] } & 122 & FOLFIRINOX & $60 \%$ & $15 \%$ & Hematological+++ \\
\hline & 122 & FOLFIRI & $34 \%$ & $6 \%$ & \\
\hline \multirow[t]{2}{*}{ Skof E (2009) [46] } & 41 & XELIRI & $49 \%$ & $24 \%$ & Equivalent \\
\hline & 46 & FOLFIRI & $48 \%$ & $24 \%$ & \\
\hline Zhao R (2010) [47] & 48 & XELIRI & $56.3 \%$ & $42 \%$ & Diarrhea+++ \\
\hline
\end{tabular}


disease. It has a number of potential benefits:

(1) Increasing the percentage of resectability

(2) Achieving a limited hepatectomy

(3) Treatment of micro-metastases

(4) Evaluation of chemosensitivity of the disease and thus provides guidance about whether CT should be given after the resection of metastases.

The most important inconvenient of neoadjuvant CT is the progression of metastases during neoadjuvant CT.

The feasibility and the benefit of neoadjuvant CT have been evaluated in phase 2 studies and in one phase III randomized trial. In a phase 2 study (MIROX trial), the liver resection was performed after six cycles of FOLFOX CT. The ORR was $77 \%$ and the curative resection rate was $91 \%$. The 2 year overall survival rate was $89 \%$. The treatment was generally well tolerated; the main toxicities were grade 3 to 4 neutropenia and thrombocytopenia [48]. At present, only one randomized phase III trial investigating the role of perioperative $\mathrm{CT}$ in patients with resectable liver metastases has been published in the English literature. This parallel-group study conducted by the EORTC intergroup (EORTC Intergroup trial 40983) reports the final data for PFS. Three hundred 64 patients with colorectal cancer and up to 4 liver metastases were randomly assigned to either six cycles (3 months) of FOLFOX4 before and six cycles (3 months) after surgery or to surgery alone (182 in perioperative CT group vs. 182 in surgery group) (Figure 1). The primary objective was PFS. In the perioperative CT group, 151 (83\%) patients were resected vs. 152 (84\%) in the surgery group. The absolute increase in rate of PFS at 3 years was $7.3 \%(p=0.058)$ in randomised patients; 8.1\% $(\mathrm{p}=0.041)$ in eligible patients; and 9.2\% $(\mathrm{p}=$ 0.025 ) in patients undergoing resection. Reversible postoperative complications occurred more often in perioperative CT than group than in surgery alone group

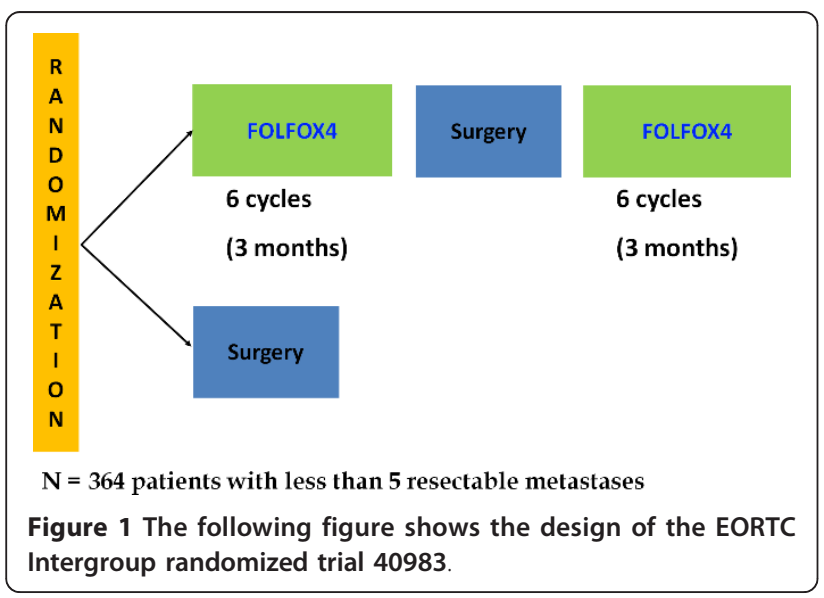

( $25 \%$ vs. $16 \% ; \mathrm{p}=0.04)$. Operative mortality was less than $1 \%$ in both treatment groups [9].

The combination of targeted agents with cytotoxic therapy showed high ORR and thus warrants assessment in the perioperative setting [24-29]. At least 4 phases II trials assessing the role of targeted therapies in preoperative setting were published (table 4) [49-52]. These studies showed that bevacizumab and cetuximab in combination with the standard CT improve ORR (70$78 \%)$ and resectability rates (60-93\%) in patient with initially unresectable or potentially resectable CRLM, without inacceptable perioperative complications. Several randomized trials are ongoing to confirm theses preliminaries results. In a phase III study conducted by the EORTC group [EORTC 40051 BOS (Biologics, Oxaliplatin and Surgery) trial] the investigators assess the perioperative CT based on cetuximab plus FOLOFOX with or without bevacizumab in patients with resectable hepatic metastases from colorectal cancer [53]. In another phase III study, the NCI group investigates the benefit of adding cetuximab to FOLFOX in perioperative setting [54].

\section{Adjuvant chemotherapy}

In the past, the standard treatment of patients with resectable liver metastasis was surgical resection alone. Thereafter, CT (neoadjuvant or adjuvant) was introduced in the multidisciplinary management in light of several investigations.

Adjuvant systemic CT is defined by the administration of CT after complete resection of CRLM. It has the aim to reduce the risk of recurrence and to improve patient survival.

There are 2 theoretical rational for adjuvant CT after liver resection: (1) the presence of cancer cells "dormant" in the remaining liver; and (2) the benefit of adjuvant $\mathrm{CT}$ after surgery for stage III colorectal cancers [55].

In analogy to stage III disease, adjuvant CT or pseudoadjuvant $\mathrm{CT}$ was assessed after the complete resection of all liver disease in two phase III trials using a similar design, but closed prematurely because of slow accrual; The pooled analysis based on individual data from these two trials was also published. A third and fourth phase III studies were conducted to compares two different adjuvant $\mathrm{CT}$ regimens (table 5) [56-60].

In the first 2 phase III studies, the patients were randomized between two arms, one experimental arm testing adjuvant CT containing 5FU/LV bolus regimen for 6 months, and a control arm treated by surgery alone. In the first study (Fédération Francophone de Cancérologie Digestive [FFCD] Trial 9002)including 173 patients, the differences in 5-year PFS and 5-year OS between the two arms were not significant, $33.5 \%$ vs. $26.7 \%$ and $51 \%$ 
Table 4 Selected phase II trials investigating targeted therapies in preoperative setting

\begin{tabular}{|c|c|c|c|c|c|c|}
\hline Auto (year) & $\begin{array}{c}\text { Type of } \\
\text { metastases }\end{array}$ & No & Treatments & $\begin{array}{l}\text { Resectability } \\
\text { rate }\end{array}$ & ORR & $\begin{array}{l}\text { Perioperative } \\
\text { complications }\end{array}$ \\
\hline $\begin{array}{l}\text { Gruenberger } \\
\text { (2008) [49] }\end{array}$ & $\begin{array}{l}\text { Potentially } \\
\text { resectable }\end{array}$ & 56 & $\begin{array}{l}\text { Bevacizumab + } \\
\quad \text { XELOX }\end{array}$ & $93 \%$ & $73 \%(C R=8.9 \% ; P R=64.3 \%)$ & Acceptable \\
\hline $\begin{array}{l}\text { Wong (2011) } \\
\text { [50] }\end{array}$ & $\begin{array}{l}\text { Not suitable for } \\
\text { upfront resection }\end{array}$ & 46 & $\begin{array}{l}\text { Bevacizumab + } \\
\text { XELOX }\end{array}$ & $40 \%$ & $78 \%$ & $\begin{array}{l}\text { No grade } 3-4 \\
\text { complications }\end{array}$ \\
\hline $\begin{array}{l}\text { Shimada } \\
\text { (2011) [51] }\end{array}$ & Unresectable & 7 & $\begin{array}{l}\text { Bevacizumab }+ \\
\text { FOLFIRINOX }\end{array}$ & $71 \%$ & $100 \%$ & $\begin{array}{l}\text { No grade } 3-4 \\
\text { complications }\end{array}$ \\
\hline $\begin{array}{l}\text { Folprecht } \\
\text { (2010) [52] }\end{array}$ & Unresectable & 114 & $\begin{array}{l}\text { Cetuximab }+ \\
\text { FOLFOX or FOLFIRI }\end{array}$ & $60 \%$ & $\begin{array}{c}70 \% \text { in K-RAS wild type tumors (RO }=34 \%: 38 \% \\
\text { with FOLFOX vs 30\% with FOLFIRI) }\end{array}$ & Acceptable \\
\hline
\end{tabular}

Abbreviations. ORR: overall response rate; CR: complete response; PR: partial response; R0: complete resection with free margins

vs. $42 \%$, respectively. However, it has shown a PFS benefit for CT in multivariate analysis (Cox model for PFS: odds ratio $=0.66, \mathrm{P}=0.028$ ) [57]. The second randomized study is a multicenter study conducted by the EORTC/NCIC/GIVIO group, (European Organization for Research and Treatment of Cancer/National Cancer Institute of Canada Clinical Trials Group/Gruppo Italiano di Valutazione Interventi in Oncologia [ENG] trial), including 129 patients. The results at 4 years did not show any difference between the 2 groups either in PFS (45\% vs. $35 \%$ ) and OS (57\% vs. $47 \%$ ) [56]. The pooled analysis using the individual data from these two studies was presented at the ASCO 2006 annual meeting and was recently published. This meta-analysis showed a marginal statistical significance in PFS $(p=0.095)$ and OS $(p=0.058)$ in favor of adjuvant chemotherapy. In addition, a multivariate analysis of three factors (treatment groups, the number of metastases, and relapse-free interval before metastasis), suggested the benefit for CT [58].

A third randomized study comparing two adjuvant CT treatments, FOLFIRI and 5FU/LV, was conducted and recently published by a French team. Three hundred 22 completely resected (R0) patients were included in this study. In the published article, the authors concluded that there were no differences in PFS (first end point) and in OS between the $2 \mathrm{CT}$ arms. However, in the patients treated early within 42 days of surgery, the FOLFIRI CT same to do better than 5FU/LV CT (PFS: $\mathrm{p}=0.17)$ [59].

Finally, a fourth trial has compared adjuvant treatment associating bevacizumab to XELOX vs. XELOX alone after radical resection of CRLM. Due to slow accrual, the study was closed early, after inclusion of 79 patients. At last follow-up, the 2 year PFS survival rate (first end point) was $70 \%$ vs. $52 \%$ in favor of Bevacizumab arm, however, the difference was not significant $(\mathrm{p}=0.074)$. No significant differences in toxicity between the 2 arms were found [60].

\section{Liver injuries related to neoadjuvant chemotherapy}

Although preoperative CT has many advantages, there has been growing concern about the potential for hepatotoxicity. The types of injuries observed in the liver specimens from patients treated with preoperative CT include steatosis, steatohepatitis, and sinusoidal injuries. These pathologies have showed to be drug specific as well as related to the duration of CT.

\section{(A) Steatosis and steatohepatitis}

Steatosis is defined by the accumulation of lipids in the hepatocyte. Its prevalence rages between 16 to $31 \%$ increasing to $46-75 \%$ in heavily consumed alcohol and obese patients. In the later stages, steatosis is accompanied by inflammation and balloonisation which lead to

Table 5 Randomized trials and metaanalyses evaluating the role systemic adjuvant chemotherapy in patients with completely resected colorectal liver metastases

\begin{tabular}{|c|c|c|c|c|c|}
\hline Authors (year) & $\begin{array}{l}\text { Type of } \\
\text { study }\end{array}$ & No & $\begin{array}{l}\text { Randomized postoperative } \\
\text { chemotherapy }\end{array}$ & Median PFS (months) & Median OS (months) \\
\hline $\begin{array}{l}\text { Langer B (2002) } \\
{[56]}\end{array}$ & Phase III & 129 & $5 F U / L V$ & No difference & No difference \\
\hline Portier (2006) [57] & Phase III & 173 & $5 F U / L V$ & 24.4 vs. $16.6(p=0.028)$ & 62.1 vs. $46.4(p=0.13)$ \\
\hline Mirty (2006) [58] & $\begin{array}{l}\text { Pooled } \\
\text { analysis }\end{array}$ & 278 & $5 F U / L V$ & 27.9 vs. $18 . .8(p=0.059)$ & $\begin{array}{c}61.1 \text { vs. } 46.9(p= \\
0.125)\end{array}$ \\
\hline Ychou (2009) [59] & Phase III & 306 & FOLFIRI vs. 5FU/LV & 24.7 vs. $21.6(p=0.44)$ & No difference \\
\hline Voest (2011) [60] & Phase III & 79 & Bevacizumab + XELOX vs. XELOX & 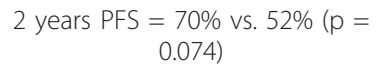 & - \\
\hline
\end{tabular}


fibrosis, and is termed steatohepatitis. Steatohepatitis can lead to significant decrease in liver function. Over a 10 -year period, approximately $9 \%-20 \%$ of patients with steatohepatitis develop cirrhosis. Of the patients who develop cirrhosis, $22 \%-33 \%$ of them develop end-stage liver disease [61-66]. Analysis of the impact of steatosis on outcome after liver resection suggests that morbidity is increased but not mortality $[67,68]$. While steatohepatitis may be associated with increased 90-day mortality due to liver failure after surgery [69].

\section{(B) Vascular damage or sinusoidal obstruction syndrome}

Sinusoidal obstruction syndrome results from damage to endothelial cells lining the sinusoids of the liver [70,71]. It can lead to portal hypertension, ascites, hyperbilirubinemia, and in severe cases, liver failure. One of the sign of sinusoidal obstruction syndrome is sinusoidal dilation. Analysis of the impact of vascular lesions on outcome following liver resection suggests that sinusoidal injury increases the risk of operative bleeding but does not increase perioperative morbidity and mortality $[69,72]$.

\section{(C) Drug specific toxicity}

Liver damage following CT has showed to be drug specific as well as related to the duration of $\mathrm{CT}$. It was reported that $5 \mathrm{FU}$ can be associated with an increased risks of severe steatosis [73]. Oxaliplatin based combination regimen is associated with an increased risk of vascular lesions of the liver $[69,72,74]$. In other reports, irinotecan-containing regimens was associated with increased risks of steatosis and steatohepatitis $[67,69,75]$

VEGF plays a critical role in liver regeneration. Consequently, it is possible that hepatic regeneration could be reduced in patients undergoing liver resection following VEGF blockage [76]. The results of 2 preclinical investigations are inconsistent regarding the effect of
EGFR inhibition on hepatic regeneration; the first study showed strong evidence that EGFR is essential in hepatic regeneration, however, the second study showed that cetuximab does not adversely affect liver resection in mice $[77,78]$. Until further evidence is obtained, it is reasonable to allow a $6 / 8$ week interval between the last administration of bevacizumab/cetuximab and surgery.

\section{(D) The impact of chemotherapy duration}

Two studies clearly showed that the morbidity rate is related to the duration of $\mathrm{CT}$ administered. In the first study with more than 12 courses of CT, was associated with higher risk of post operative complications compared with < or 12 courses. In the second study, the authors showed that postoperative morbidity was higher in patients receiving more than 6 cycles of CT before surgery [72,79]. More recently, safety data of the EORTC 40983/EPOC phase III study showed that the administration of 6 cycles of FOLFOX before surgery appears feasible; the mortality rate was very low (close to $1 \%)$ and the rate of reversible complications was acceptable [9].

\section{Treatment recommendations (figure 2) $[32,33,80]$}

Treatment choices for patients with CRLM should be discussed in multidisciplinary team meetings (surgeon, medical oncologist, radiation oncologist, radiologist, pathologist...)

\section{(A) Resectable colorectal liver metastases}

Perioperative treatment with 3 months (6 cycles) of FOLFOX4 CT was compatible with major liver surgery, improved PFS in resectable patients, and should be considered as a standard of care in patients with resectable CRLM.

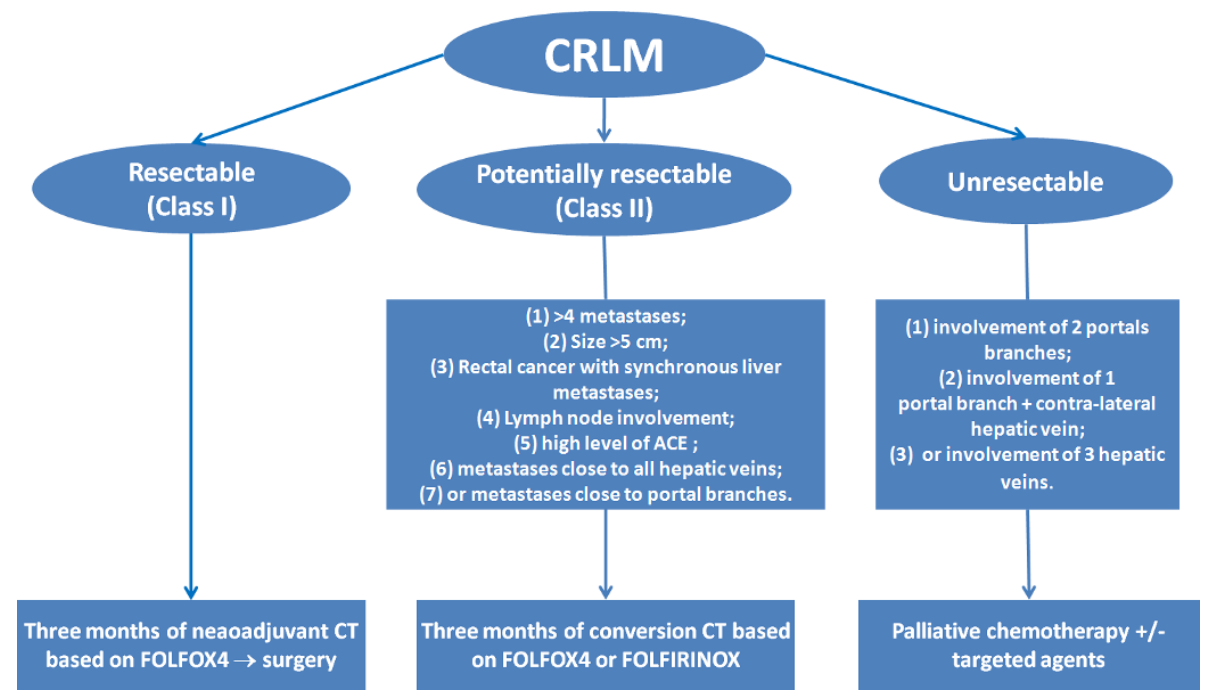

Figure 2 The following figure summarizes the treatment recommendations. 
In the case of primary surgery, adjuvant $\mathrm{CT}$ based on 5FU/LV, FOLFOX4/XELOX or FOLFIRI regimens for 6 months should be considered as an option in patient with completely resected liver metastases.

\section{(B)Potentially resectable colorectal liver metastases}

Neoadjuvant CT called conversion CT based on 3 months (6 cycles) of FOLFOX4 or FOLFIRINOX regimens should be considered to enhance the chance of cure of patient with initially unresectable liver metastases. Resection should be discussed in multidisciplinary team meetings.

\section{(C)Liver metastases those are unlikely to ever become} resectable

Palliative CT based on FOLFOX4/XELOX, FOLFIRI, with or without biological therapies should be considered.

In this setting, the possibility of doing a resection should not be excluded. Resection should be discussed in multidisciplinary team meetings.

Table 6 summarizes the most used CT regimens in metastatic CRC.

Table 6 The most used chemotherapy regimens in the treatment of metastatic colorectal cancer

\begin{tabular}{|c|c|c|c|c|c|c|}
\hline \multirow[t]{2}{*}{ Regimen } & \multirow{2}{*}{$\begin{array}{l}\text { Cycle } \\
\text { length }\end{array}$} & \multicolumn{5}{|c|}{ Drogues and doses } \\
\hline & & 1 & 2 & 3 & 4 & 5 \\
\hline $\begin{array}{l}\text { 5FU Mayo } \\
\text { clinic }\end{array}$ & 4 weeks & LV $20 \mathrm{mg} / \mathrm{m}^{2} / \mathrm{D}$ on D $1-5$ & 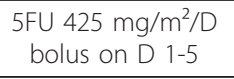 & - & - & - \\
\hline $\begin{array}{l}\text { 5FU/LV (de } \\
\text { Gramont) [17] }\end{array}$ & 2 weeks & $\begin{array}{c}\mathrm{LV} 200 \mathrm{mg} / \mathrm{m}^{2} \text { over } 2 \mathrm{~h} \text { on D1 } \\
\text { and D2 }\end{array}$ & $\begin{array}{c}\text { 5FU } 400 \mathrm{mg} / \mathrm{m}^{2} \\
\text { bolus on D1 and } \\
\text { D2 }\end{array}$ & $\begin{array}{c}\text { FUU } 600 \mathrm{mg} / \mathrm{m}^{2} \mathrm{CIVl} \\
\text { over } 22 \mathrm{~h} \text { on D1 and } \\
\text { D2 }\end{array}$ & - & - \\
\hline FOLFOX4 [17] & 2 weeks & $\begin{array}{c}\text { Oxaliplatin } 85 \mathrm{mg} / \mathrm{m}^{2} \text { over } 2 \mathrm{~h} \\
\text { on D1 }\end{array}$ & $\begin{array}{l}\mathrm{LV} 200 \mathrm{mg} / \mathrm{m}^{2} \\
\text { over } 2 \mathrm{~h} \text { on D1 } \\
\text { and D2 }\end{array}$ & $\begin{array}{c}\text { 5FU } 400 \mathrm{mg} / \mathrm{m}^{2} \\
\text { bolus on D1 and D2 }\end{array}$ & $\begin{array}{c}\text { 5FU } 600 \mathrm{mg} / \mathrm{m}^{2} \mathrm{CIVl} \\
\text { over } 22 \mathrm{~h} \text { on D1 and } \\
\text { D2 }\end{array}$ & - \\
\hline $\begin{array}{l}\text { Modified } \\
\text { FOLFOX6 }\end{array}$ & 2 weeks & $\begin{array}{c}\text { Oxaliplatin } 85 \mathrm{mg} / \mathrm{m}^{2} \text { over } 2 \mathrm{~h} \\
\text { on } \mathrm{D} 1\end{array}$ & $\begin{array}{l}\mathrm{LV} 200 \mathrm{mg} / \mathrm{m}^{2} \\
\text { over } 2 \mathrm{~h} \text { on D1 } \\
\text { and D2 }\end{array}$ & $\begin{array}{l}\text { 5FU } 400 \mathrm{mg} / \mathrm{m}^{2} \\
\text { bolus on D1 }\end{array}$ & $\begin{array}{l}\text { 5FU } 2400 \mathrm{mg} / \mathrm{m}^{2} \mathrm{ClVl} \\
\text { over } 46 \mathrm{~h} \text { on D1 }\end{array}$ & \\
\hline$\overline{X E L O X}$ & 3 weeks & $\begin{array}{c}\text { Oxaliplatin } 130 \mathrm{mg} / \mathrm{m}^{2} \text { over } 2 \\
\text { h on D1 }\end{array}$ & $\begin{array}{l}\text { Capecitabine } 1 \mathrm{~g} / \\
\mathrm{m}^{2} \mathrm{BD} \text { on } \mathrm{D} 1-14\end{array}$ & - & - & - \\
\hline FOLFIRI [19] & 2 weeks & $\begin{array}{c}\text { Irinotecan } 180 \mathrm{mg} / \mathrm{m}^{2} \text { over } 1 \mathrm{~h} \\
\text { on } \mathrm{D} 1\end{array}$ & $\begin{array}{l}\mathrm{LV} 200 \mathrm{mg} / \mathrm{m}^{2} \\
\text { over } 2 \mathrm{~h} \text { on D1 } \\
\text { and D2 }\end{array}$ & $\begin{array}{c}\text { 5FU } 400 \mathrm{mg} / \mathrm{m}^{2} \\
\text { bolus on D1 and D2 }\end{array}$ & $\begin{array}{c}\text { 5FU } 600 \mathrm{mg} / \mathrm{m} 2 \mathrm{CIVl} \\
\text { over } 22 \mathrm{~h} \text { on D1 and } \\
\text { D2 }\end{array}$ & - \\
\hline$\overline{X E L I R I}$ & 3 weeks & $\begin{array}{c}\text { Oxaliplatin } 130 \mathrm{mg} / \mathrm{m}^{2} \text { over } 2 \\
\text { h on D1 }\end{array}$ & $\begin{array}{l}\text { Capecitabine } 1 \mathrm{~g} / \\
\mathrm{m}^{2} \mathrm{BD} \text { on } \mathrm{D} 1-14\end{array}$ & - & - & - \\
\hline $\begin{array}{l}\text { FOLFIRINOX } \\
\text { (Italy) [21] }\end{array}$ & 2 weeks & $\begin{array}{c}\text { Irinotecan } 165 \mathrm{mg} / \mathrm{m}^{2} \text { over } 1 \mathrm{~h} \\
\text { on } \mathrm{D} 1\end{array}$ & $\begin{array}{c}\text { Oxaliplatin } 85 \mathrm{mg} / \\
\mathrm{m}^{2} \text { over } 2 \mathrm{~h} \text { on } \\
\text { D1 }\end{array}$ & LV $200 \mathrm{mg} / \mathrm{m}^{2}$ on D1 & $\begin{array}{c}\text { 5FU } 400 \mathrm{mg} / \mathrm{m}^{2} \text { bolus } \\
\text { on D1 }\end{array}$ & $\begin{array}{l}\text { 5FU } 3200 \mathrm{mg} / \mathrm{m} 2 \\
\text { CIVl } 48 \mathrm{~h} \text { on D1 }\end{array}$ \\
\hline $\begin{array}{l}\text { FOLFIRINOX } \\
\text { (France) [45] }\end{array}$ & 2 weeks & $\begin{array}{c}\text { Irinotecan } 180 \mathrm{mg} / \mathrm{m}^{2} \text { over } 1 \mathrm{~h} \\
\text { on } \mathrm{D} 1\end{array}$ & $\begin{array}{l}\text { Oxaliplatin } 85 \mathrm{mg} / \\
\mathrm{m}^{2} \text { over } 2 \mathrm{~h} \text { on } \\
\text { D1 }\end{array}$ & LV $400 \mathrm{mg} / \mathrm{m}^{2}$ on D1 & $\begin{array}{c}\text { 5FU } 400 \mathrm{mg} / \mathrm{m}^{2} \text { bolus } \\
\text { on } \mathrm{D} 1\end{array}$ & $\begin{array}{l}\text { 5FU } 2400 \mathrm{mg} / \mathrm{m} 2 \\
\text { CIVI } 48 \mathrm{~h} \text { on D1 }\end{array}$ \\
\hline $\begin{array}{l}\text { Bevacizumab } \\
+ \text { FOLFOX4 } \\
{[26]}\end{array}$ & 2 weeks & $\begin{array}{l}\text { Bevacizumab } 5 \mathrm{mg} / \mathrm{kg} \text { over } \\
30-90 \mathrm{~min} \text { on D1 }\end{array}$ & $\begin{array}{l}\text { Oxaliplatin } 85 \text { mg/ } \\
\text { m2 over } 2 \text { h D1 }\end{array}$ & $\begin{array}{l}\text { LV } 200 \mathrm{mg} / \mathrm{m}^{2} \text { over } \\
\text { 2h on D1 and D2 }\end{array}$ & $\begin{array}{l}\text { 5FU } 400 \mathrm{mg} / \mathrm{m}^{2} \text { bolus } \\
\text { on D1 and D2 }\end{array}$ & $\begin{array}{c}\text { 5FU } 600 \mathrm{mg} / \mathrm{m}^{2} \mathrm{CIVI} \\
\text { over } 22 \mathrm{~h} \text { on D1 and } \\
\text { D2 }\end{array}$ \\
\hline $\begin{array}{l}\text { Bevacizumab } \\
+ \text { XELOX [26] }\end{array}$ & 3 weeks & $\begin{array}{c}\text { Bevacizumab } 7.5 \mathrm{mg} / \mathrm{kg} \text { over } \\
30-90 \mathrm{~min} \text { on D1 }\end{array}$ & $\begin{array}{l}\text { Oxaliplatin } 130 \\
\mathrm{mg} / \mathrm{m}^{2} \text { over } 2 \mathrm{~h} \\
\text { on D1 }\end{array}$ & $\begin{array}{l}\text { Capecitabine } 1 \mathrm{~g} / \mathrm{m}^{2} \\
\text { BD on D1-14 }\end{array}$ & - & - \\
\hline $\begin{array}{l}\text { Bevacizumab } \\
+ \text { FOLFIRI [25] }\end{array}$ & 2 weeks & $\begin{array}{c}\text { Bevacizumab } 5 \mathrm{mg} / \mathrm{kg} \text { over } \\
30-90 \mathrm{~min} \text { on D1 }\end{array}$ & $\begin{array}{l}\text { Irinotecan } 180 \\
\mathrm{mg} / \mathrm{m}^{2} \text { over } 1 \mathrm{~h} \\
\mathrm{D} 1\end{array}$ & $\begin{array}{l}\text { LV } 200 \mathrm{mg} / \mathrm{m}^{2} \text { over } \\
\text { 2h on D1 and D2 }\end{array}$ & $\begin{array}{l}\text { 5FU } 400 \mathrm{mg} / \mathrm{m}^{2} \text { bolus } \\
\text { on } \mathrm{D} 1 \text { and } \mathrm{D} 2\end{array}$ & $\begin{array}{c}\text { 5FU } 600 \mathrm{mg} / \mathrm{m}^{2} \mathrm{CIVl} \\
\text { over } 22 \mathrm{~h} \text { on D1 and } \\
\text { D2 }\end{array}$ \\
\hline $\begin{array}{l}\text { Cetuximab + } \\
\text { FOLFIRI } \\
\text { (K-RAS wild } \\
\text { type) [28] }\end{array}$ & 2 weeks & $\begin{array}{c}\text { Cetuximab } 400 \mathrm{mg} / \mathrm{m}^{2} \text { over } 2 \\
\text { h on D1 then } 250 \mathrm{mg} / \mathrm{m}^{2} \\
\text { weekly }\end{array}$ & $\begin{array}{l}\text { Irinotecan } 180 \\
\mathrm{mg} / \mathrm{m}^{2} \text { over } 1 \mathrm{~h} \\
\text { on } \mathrm{D} 1\end{array}$ & $\begin{array}{c}\text { LV } 200 \mathrm{mg} / \mathrm{m}^{2} \text { over } 2 \\
\text { h on D1 and D2 }\end{array}$ & $\begin{array}{l}\text { 5FU } 400 \mathrm{mg} / \mathrm{m}^{2} \text { bolus } \\
\text { on D1 and D2 }\end{array}$ & $\begin{array}{c}\text { 5FU } 600 \mathrm{mg} / \mathrm{m}^{2} \mathrm{CIVl} \\
\text { over } 22 \mathrm{~h} \text { on } \mathrm{D} 1 \text { and } \\
\text { D2 }\end{array}$ \\
\hline $\begin{array}{l}\text { Cetuximab + } \\
\text { FOLFOX } \\
\text { (K-RAS wild } \\
\text { type) [29] }\end{array}$ & 2 weeks & $\begin{array}{c}\text { Cetuximab } 400 \mathrm{mg} / \mathrm{m}^{2} \text { over } 1 \\
\text { h on D1 then } 250 \mathrm{mg} / \mathrm{m}^{2} \\
\text { weekly }\end{array}$ & $\begin{array}{l}\text { Oxaliplatin } 85 \mathrm{mg} / \\
\mathrm{m}^{2} \text { over } 2 \mathrm{~h} \text { on } \\
\text { D1 }\end{array}$ & $\begin{array}{l}\mathrm{LV} 200 \mathrm{mg} / \mathrm{m}^{2} \text { over } \\
2 \mathrm{~h} \text { on D1 and D2 }\end{array}$ & $\begin{array}{l}\text { 5FU } 400 \mathrm{mg} / \mathrm{m}^{2} \text { bolus } \\
\text { on } \mathrm{D} 1 \text { and } \mathrm{D} 2\end{array}$ & $\begin{array}{l}\text { 5FU } 600 \mathrm{mg} / \mathrm{m} 2 \mathrm{CIVI} \\
\text { over } 22 \mathrm{~h} \mathrm{D} 1 \text { and D2 }\end{array}$ \\
\hline
\end{tabular}

Abbreviations: $\mathrm{D}=$ day; $\mathrm{CIVI}=$ continuous intravenous infusion; $\mathrm{BD}=$ bid day 


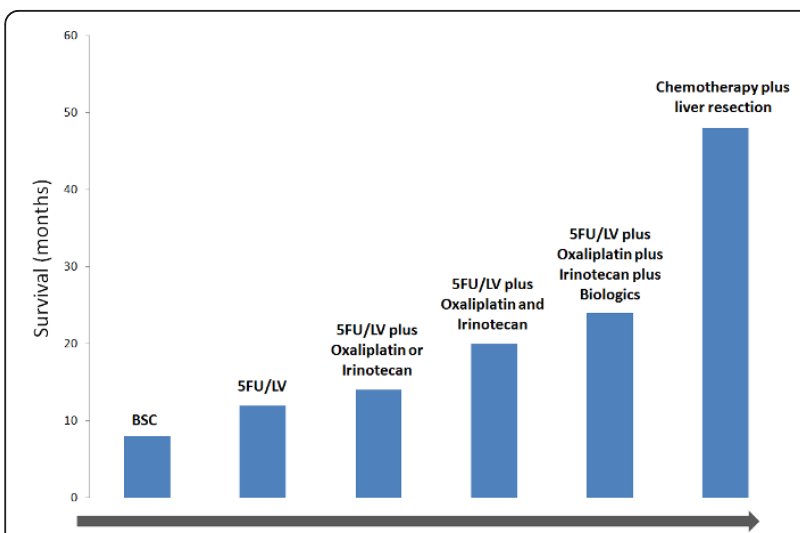

Figure 3 Figure illustrates the improvement in survival of patients with CRLM by the development of modern chemotherapy and targeted therapies and mainly by the consideration of resection as part of the multidisciplinary management.

\section{Conclusion}

The prognosis of patients with metastatic colorectal cancer of the liver has improved significantly over the last few years (Figure 3). The management has become multidisciplinary using modern $\mathrm{CT}$ regimens and more developed surgical techniques. For patients with resectable metastases, perioperative CT based on FOLFOX4 is the treatment of choice before surgical resection according to the results of the EORTC40983 randomized trial. For patient with resectable metastases treated with primary surgery, adjuvant $\mathrm{CT}$ is a reasonable option. In the case of initially unresectable disease, conversion CT using more active combination such as FOLFIRINOX should be indicated to downsizing liver metastases and to optimize the chance of cure. If metastases are unresectable and unlikely to be resectable, palliative CT with or without targeted agents is the mainstay treatment. The role of targeted therapy in neoadjuvant setting will be defined in the near future. Therapeutic investigations should be continued with the development of more efficient regimens, newer surgical and ablative techniques, to improve treatment results of colorectal liver metastases.

\section{Abbreviations}

CRC : colorectal cancer; CRLM : colorectal liver metastases; CRR : complete response rate; $\mathbf{C T}$ : chemotherapy; EGFR : epidermal growth factor receptor; 5FU : 5-fluorouracil; HAI : hepatic arterial infusion; LV : folinic acid; ORR overall response rate; OS : overall survival; PFS : progression free survival (or disease free survival); VEGF : vascular endothelial growth factor

\section{Acknowledgements}

We sincerely thank Mohammed Ismaili, Professor of Microbiology from Moulay Ismail University, Meknes, Morocco.

\section{Authors' contributions}

$\mathrm{NI}$ is involved in concept design, in data collection, drafting and critically revising the manuscript.
Competing interests

The author declares that they have no competing interests.

Received: 28 September 2011 Accepted: 24 November 2011

Published: 24 November 2011

\section{References}

1. Jemal A, Bray F, Center MM, Ferlay J, Ward E, Forman D: Global cancer statistics. CA Cancer J Clin 2011, 61(2):69-90

2. Adam R: Chemotherapy and surgery: new perspectives on the treatment of unresectable liver metastases. Ann Oncol 2003, 14(Suppl 2):ii13-6.

3. Van Cutsem E, Nordlinger B, Adam R, Köhne CH, Pozzo C, Poston G, Ychou M, Rougier P, European Colorectal Metastases Treatment Group: Towards a pan-European consensus on the treatment of patients with colorectal liver metastases. Eur J Cancer 2006, 42(14):2212-21.

4. Choti MA, Sitzmann JV, Tiburi MF, Sumetchotimetha W, Rangsin R, Schulick RD, Lillemoe KD, Yeo CJ, Cameron JL: Trends in long-term survival following liver resection for hepatic colorectal metastases. Ann Surg 2002, 235(6):759-66.

5. Fong $Y$, Cohen AM, Fortner JG, Enker WE, Turnbull AD, Coit DG, Marrero AM, Prasad M, Blumgart LH, Brennan MF: Liver resection for colorectal metastases. J Clin Oncol 1997, 15(3):938-46.

6. Scheele J, Stang R, Altendorf-Hofmann A, Paul M: Resection of colorectal liver metastases. World J Surg 1995, 19(1):59-71.

7. Rougier P, Milan C, Lazorthes F, Fourtanier G, Partensky C, Baumel H, Faivre J: Prospective study of prognostic factors in patients with unresected hepatic metastases from colorectal cancer. Fondation Française de Cancérologie Digestive. Br J Surg 1995, 82(10):1397-400.

8. Nordlinger $B$, Van Cutsem E, Rougier P, Köhne CH, Ychou M, Sobrero A, Adam R, Arvidsson D, Carrato A, Georgoulias V, Giuliante F, Glimelius B, Golling M, Gruenberger T, Tabernero J, Wasan H, Poston G, European Colorectal Metastases Treatment Group: Does chemotherapy prior to liver resection increase the potential for cure in patients with metastatic colorectal cancer? A report from the European ColorectalMetastases Treatment Group. Eur J Cancer 2007, 43(14):2037-45, Epub 2007 Sep 4.

9. Nordlinger B, Sorbye H, Glimelius B, Poston GJ, Schlag PM, Rougier P, et al: Perioperative chemotherapy with FOLFOX4 and surgery versus surgery alone for resectable liver metastases from colorectal cancer (EORTC Intergroup trial 40983): a randomised controlled trial. Lancet 2008, 371(9617):1007-16

10. Adam R, Delvart V, Pascal G, Valeanu A, Castaing D, Azoulay D, Giacchetti S, Paule B, Kunstlinger F, Ghémard O, Levi F, Bismuth $\mathrm{H}$ : Rescue surgery for unresectable colorectal liver metastases downstaged by chemotherapy: a model to predict long-term survival. Ann Surg 2004, 240(4):644-57, discussion 657-8.

11. Kemeny N, Huang Y, Cohen AM, Shi W, Conti JA, Brennan MF, Bertino JR Turnbull AD, Sullivan D, Stockman J, Blumgart LH, Fong Y: Hepatic arterial infusion of chemotherapy after resection of hepatic metastases from colorectal cancer. N Engl J Med 1999, 341(27):2039-48.

12. Kemeny MM, Adak S, Gray B, Macdonald JS, Smith T, Lipsitz S, Sigurdson ER, O'Dwyer PJ, Benson AB: Combined-modality treatment for resectable metastatic colorectal carcinoma to the liver: surgical resection of hepatic metastases in combination with continuous infusion of chemotherapyan intergroup study. J Clin Oncol 2002, 20(6):1499-505.

13. Kemeny $N E$, Gonen $M$ : Hepatic arterial infusion after liver resection. $N$ Engl I Med 2005, 352(7):734-5.

14. Scheithauer W, Rosen H, Kornek GV, Sebesta C, Depisch D: Randomised comparison of combination chemotherapy plus supportive care with supportive care alone in patients with metastatic colorectal cancer. BMJ 1993, 306(6880):752-5.

15. Mayer RJ: Moving beyond fluorouracil for colorectal cancer. N Engl J Med 2000, 343(13):963-4.

16. Saltz LB, Cox JV, Blanke C, Rosen LS, Fehrenbacher L, Moore MJ, Maroun JA, Ackland SP, Locker PK, Pirotta N, Elfring GL, Miller LL: Irinotecan plus fluorouracil and leucovorin for metastatic colorectal cancer. Irinotecan Study Group. N Engl I Med 2000, 343(13):905-14.

17. de Gramont A, Figer A, Seymour M, Homerin M, Hmissi A, Cassidy J, Boni C, Cortes-Funes $\mathrm{H}$, Cervantes A, Freyer G, Papamichael D, Le Bail N, Louvet C, Hendler D, de Braud F, Wilson C, Morvan F, Bonetti A: Leucovorin and fluorouracil with or without oxaliplatin as first-line treatment in advanced colorectal cancer. J Clin Oncol 2000, 18(16):2938-47. 
18. Giacchetti S, Perpoint B, Zidani R, Le Bail N, Faggiuolo R, Focan C, Chollet P, Llory JF, Letourneau Y, Coudert B, Bertheaut-Cvitkovic F, LarregainFournier D, Le Rol A, Walter S, Adam R, Misset JL, Lévi F: Phase III multicenter randomized trial of oxaliplatin added to chronomodulated fluorouracil-leucovorin as first-line treatment of metastatic colorectal cancer. J Clin Oncol 2000, 18(1):136-47.

19. Tournigand C, André T, Achille E, Lledo G, Flesh M, Mery-Mignard D, Quinaux E, Couteau C, Buyse M, Ganem G, Landi B, Colin P, Louvet C, de Gramont A: FOLFIRI followed by FOLFOX6 or the reverse sequence in advanced colorectal cancer: a randomized GERCOR study. J Clin Oncol 2004, 22(2):229-37

20. Grothey A, Sargent D, Goldberg RM, Schmoll HJ: Survival of patients with advanced colorectal cancer improves with the availability of fluorouracilleucovorin, irinotecan, and oxaliplatin in the course of treatment. J Clin Oncol 2004, 22(7):1209-14.

21. Falcone A, Ricci S, Brunetti I, Pfanner E, Allegrini G, Barbara C, Crinò L, Benedetti G, Evangelista W, Fanchini L, Cortesi E, Picone V, Vitello S, Chiara S, Granetto C, Porcile G, Fioretto L, Orlandini C, Andreuccetti M Masi G, Gruppo Oncologico Nord Ovest: Phase III trial of infusional fluorouracil, leucovorin, oxaliplatin, and irinotecan (FOLFOXIRI) compared with infusional fluorouracil, leucovorin, and irinotecan (FOLFIRI) as first-line treatment for metastatic colorectal cancer: the Gruppo Oncologico Nord Ovest. J Clin Oncol 2007, 25(13):1670-6.

22. Souglakos J, Androulakis N, Syrigos K, Polyzos A, Ziras N, Athanasiadis A, Kakolyris S, Tsousis S, Kouroussis Ch, Vamvakas L, Kalykaki A, Samonis G, Mavroudis D, Georgoulias V: FOLFOXIRI (folinic acid, 5-fluorouracil, oxaliplatin and irinotecan) vs FOLFIRI (folinic acid, 5-fluorouracil and irinotecan) as first-line treatment in metastatic colorectal cancer (MCC): a multicentre randomised phase III trial from the Hellenic Oncology Research Group (HORG). Br J Cancer 2006, 94(6):798-805.

23. Montagnani F, Chiriatti A, Turrisi G, Francini G, Fiorentini G: A systematic review of FOLFOXIRI chemotherapy for the first-line treatment of metastatic colorectal cancer: improved efficacy at the cost of increased toxicity. Colorectal Dis 2011, 13(8):846-52.

24. Hurwitz H, Fehrenbacher L, Novotny W, Cartwright T, Hainsworth J, Heim W, Berlin J, Baron A, Griffing S, Holmgren E, Ferrara N, Fyfe G, Rogers B, Ross R, Kabbinavar F: Bevacizumab plus irinotecan, fluorouracil, and leucovorin for metastatic colorectal cancer. N Engl J Med 2004, 350(23):2335-42

25. Fuchs CS, Marshall J, Mitchell E, Wierzbicki R, Ganju V, Jeffery M, Schulz J, Richards D, Soufi-Mahjoubi R, Wang B, Barrueco J: Randomized, controlled trial of irinotecan plus infusional, bolus, or oral fluoropyrimidines in firstline treatment of metastatic colorectal cancer: results from the BICC-C Study. J Clin Oncol 2007, 25(30):4779-86.

26. Saltz LB, Clarke S, Díaz-Rubio E, Scheithauer W, Figer A, Wong R, Koski S, Lichinitser M, Yang TS, Rivera F, Couture F, Sirzén F, Cassidy J: Bevacizumab in combination with oxaliplatin-based chemotherapy as first-line therapy in metastatic colorectal cancer: a randomized phase III study. J Clin Oncol 2008, 26(12):2013-9.

27. Van Cutsem E, Rivera F, Berry S, Kretzschmar A, Michael M, DiBartolomeo M, Mazier MA, Canon JL, Georgoulias V, Peeters M, Bridgewater J, Cunningham D, First BEAT investigators: Safety and efficacy of first-line bevacizumab with FOLFOX, XELOX, FOLFIRI and fluoropyrimidines in metastatic colorectal cancer: the BEAT study. Ann Oncol 2009, 20(11):1842-7.

28. Van Cutsem E, Köhne $\mathrm{CH}$, Hitre E, Zaluski J, Chang Chien CR, Makhson A, D'Haens G, Pintér T, Lim R, Bodoky G, Roh JK, Folprecht G, Ruff P, Stroh C, Tejpar S, Schlichting M, Nippgen J, Rougier P: Cetuximab and chemotherapy as initial treatment for metastatic colorectal cancer. $N$ Engl J Med 2009, 360(14):1408-17.

29. Bokemeyer C, Bondarenko I, Makhson A, Hartmann JT, Aparicio J, de Braud F, Donea S, Ludwig H, Schuch G, Stroh C, Loos AH, Zubel A, Koralewski P: Fluorouracil, leucovorin, and oxaliplatin with and without cetuximab in the first-line treatment of metastatic colorectal cancer. $J$ Clin Oncol 2009, 27(5):663-71.

30. Nordlinger B, Guiguet M, Vaillant JC, Balladur P, Boudjema K, Bachellier P, Jaeck D: Surgical resection of colorectal carcinoma metastases to the liver. A prognostic scoring system to improve case selection, based on 1568 patients. Association Française de Chirurgie. Cancer 1996, 77(7):1254-62
31. Fong Y, Fortner J, Sun RL, Brennan MF, Blumgart LH: Clinical score for predicting recurrence after hepatic resection for metastatic colorectal cancer: analysis of 1001 consecutive cases. Ann Surg 1999, 230(3):309-18, discussion 318-21.

32. [http://thesaurus-cancerologie.snfge.org/data/ModuleDocument/publication/ 5/pdf/tmp960.html?abcpdf = 20\%2F07\%2F2010+11\%3A56\%3A00\#1377].

33. Chiche $L$, ANAES: When is first-line resection of hepatic metastasis indicated? Gastroenterol Clin Biol 2003, 27 Spec No 2:B11-3, B41-61.

34. Poston GJ, Adam R, Alberts S, Curley S, Fiqueras J, Haller D, Kunstlinger F, Mentha G, Nordlinger B, Patt Y, Primrose J, Roh M, Rougier P, Ruers T, Schmoll HJ, Valls C, Vauthey NJ, Cornelis M, Kahan JP: OncoSurge: a strategy for improving resectability with curative intent in metastatic colorectal cancer. J Clin Oncol 2005, 23(28):7125-34.

35. Rivoire M, De Cian F, Meeus P, Négrier S, Sebban H, Kaemmerlen P: Combination of neoadjuvant chemotherapy with cryotherapy and surgical resection for the treatment of unresectable liver metastases from colorectal carcinoma. Cancer 2002, 95(11):2283-92.

36. Wein A, Riedel C, Köckerling F, Martus P, Baum U, Brueckl WM, Reck T, Ott R, Hänsler J, Bernatik T, Becker D, Schneider T, Hohenberger W, Hahn EG: Impact of surgery on survival in palliative patients with metastatic colorectal cancer after first line treatment with weekly 24hour infusion of high-dose 5-fluorouracil and folinic acid. Ann Oncol 2001, 12(12):1721-7.

37. Pozzo C, Basso M, Cassano A, Quirino M, Schinzari G, Trigila N, Vellone M, Giuliante F, Nuzzo G, Barone C: Neoadjuvant treatment of unresectable liver disease with irinotecan and 5-fluorouracil plus folinic acid in colorectal cancer patients. Ann Oncol 2004, 15(6):933-9.

38. Cals L, Rixe O, François E, Favre R, Merad L, Deplanque G, Laadem A, Juin P, Bereder JM, Bernardini D, Herait P: Dose-finding study of weekly 24-h continuous infusion of 5-fluorouracil associated with alternating oxaliplatin or irinotecan in advanced colorectal cancer patients. Ann Oncol 2004, 15(7):1018-24.

39. Köhne $\mathrm{CH}$, van Cutsem E, Wils J, Bokemeyer C, El-Serafi M, Lutz MP, Lorenz M, Reichardt P, Rückle-Lanz H, Frickhofen N, Fuchs R, Mergenthaler HG, Langenbuch T, Vanhoefer U, Rougier P, Voigtmann R, Müller L, Genicot B, Anak O, Nordlinger B, European Organisation for Research and Treatment of Cancer Gastrointestinal Group: Phase III study of weekly high-dose infusional fluorouracil plus folinic acid with or without irinotecan in patients with metastatic colorectal cancer: European Organisation for Research and Treatment of Cancer Gastrointestinal Group Study 40986. J Clin Oncol 2005, 23(22):4856-65.

40. Ho WM, Ma B, Mok T, Yeo W, Lai P, Lim R, Koh J, Wong YY, King A, Leow CK, Chan AT: Liver resection after irinotecan, 5-fluorouracil, and folinic acid for patients with unresectable colorectal liver metastases: a multicenter phase II study by the Cancer Therapeutic Research Group. Ann Oncol 2005, 16(5):762-6.

41. Seium Y, Stupp R, Ruhstaller T, Gervaz P, Mentha G, Philippe M, Allal A, Trembleau C, Bauer J, Morant R, Roth AD: Oxaliplatin combined with irinotecan and 5-fluorouracil/leucovorin (OCFL) in metastatic colorectal cancer: a phase I-II study. Ann Oncol 2005, 16(5):762-6.

42. Alberts SR, Horvath WL, Sternfeld WC, Goldberg RM, Mahoney MR, Dakhil SR, Levitt R, Rowland K, Nair S, Sargent DJ, Donohue JH: Oxaliplatin, fluorouracil, and leucovorin for patients with unresectable liver-only metastases from colorectal cancer: a North Central Cancer Treatment Group phase II study. J Clin Oncol 2005, 23(36):9243-9.

43. Masi G, Cupini S, Marcucci L, Cerri E, Loupakis F, Allegrini G, Brunetti IM Pfanner E, Viti M, Goletti O, Filipponi F, Falcone A: Treatment with 5fluorouracil/folinic acid, oxaliplatin, and irinotecan enables surgical resection of metastases in patients with initially unresectable metastatic colorectal cancer. Ann Surg Oncol 2006, 13(1):58-65.

44. Rivoire M, Thezenas S, Rebischung C, Viret F, Guimbaud R, Francois E, Ducreux M, Quenet F, Desseigne F, Ychou M: Preliminary results of a randomized phase II trial comparing standard bi-therapy versus three intensified chemotherapy regimens as treatment for patients with non resectable liver metastases from colorectal cancer (LMCRC). (METHEP). $J$ Clin Oncol 2008, 26, (May 20 suppl; abstr 4075).

45. Ychou M, Viret F, Kramar A, Desseigne F, Mitry E, Guimbaud R, Delpero JR, Rivoire M, Quénet F, Portier G, Nordlinger B: Tritherapy with fluorouracil/ leucovorin, irinotecan and oxaliplatin (FOLFIRINOX): a phase II study in colorectal cancer patients with non-resectable liver metastases. Cancer Chemother Pharmacol 2008, 62(2):195-201. 
46. Skof E, Rebersek M, Hlebanja Z, Ocvirk J: Capecitabine plus Irinotecan (XELIRI regimen) compared to 5-FU/LV plus Irinotecan (FOLFIRI regimen) as neoadjuvant treatment for patients withunresectable liver-only metastases of metastatic colorectal cancer: a randomised prospective phase II trial. BMC Cancer 2009, 9:120.

47. Zhao R, Zhu J, Ji X, Cai J, Wan F, Li Q, Zhong B, Tucker S, Wang D: A phase II study of irinotecan and capecitabine for patients withunresectable liver only metastases from colorectal cancer. Jpn J Clin Oncol 2010, 40(1):10-6.

48. Taïeb J, Artru P, Paye F, Louvet C, Perez N, André T, Gayet B, Hebbar M, Goebel FM, Tournigand C, Parc R, de Gramont A: Intensive systemic chemotherapy combined with surgery for metastatic colorectal cancer: results of a phase II study. J Clin Oncol 2005, 23(3):502-9.

49. Gruenberger B, Tamandl D, Schueller J, Scheithauer W, Zielinski C, Herbst F, Gruenberger T: Bevacizumab, capecitabine, and oxaliplatin as neoadjuvant therapy for patients with potentially curable metastatic colorectal cancer. J Clin Oncol 2008, 26(11):1830-5.

50. Wong $R$, Cunningham D, Barbachano $Y$, Saffery C, Valle J, Hickish T, Mudan S, Brown G, Khan A, Wotherspoon A, Strimpakos AS, Thomas J, Compton S, Chua YJ, Chau I: A multicentre study of capecitabine, oxaliplatin plus bevacizumab as perioperative treatment of patients with poor-risk colorectal liver-only metastases not selected for upfront resection. Ann Oncol 2011, 22(9):2042-8.

51. Shimada M, Nishioka M, Hanaoka J, Mori H, Ikemoto T, Imura S, Morine $Y$, Utsunomiya T: Impact of FOLFOXIRI plus bevacizumab on resectability and survival in patients with initially unresectable liver metastases from colorectal cancer. J Clin Oncol 2011, 29, (suppl 4; abstr 621).

52. Folprecht G, Gruenberger T, Bechstein WO, Raab HR, Lordick F, Hartmann JT, Lang H, Frilling A, Stoehlmacher J, Weitz J, Konopke R, Stroszczynski C, Liersch T, Ockert D, Herrmann T, Goekkurt E, Parisi F, Köhne $\mathrm{CH}$ : Tumour response and secondary resectability of colorectal livermetastases following neoadjuvant chemotherapy with cetuximab: the CELIM randomised phase 2 trial. Lancet Oncol 2010, 11(1):38-47.

53. [http://www.clinicaltrial.gov/ct2/show/NCT00438737?term=EORTC 40051\&rank = 1]

54. [http://www.clinicaltrial.gov/ct2/show/NCT00482222?term=resectable+liver +metastasis+colorectal+cancer\&rank = 5.].

55. André T, Boni C, Mounedji-Boudiaf L, Navarro M, Tabernero J, Hickish T, Topham C, Zaninelli M, Clingan P, Bridgewater J, Tabah-Fisch I, de Gramont A, Multicenter International Study of Oxaliplatin/5-Fluorouracil/ Leucovorin in the Adjuvant Treatment of Colon Cancer (MOSAIC) Investigators: Oxaliplatin, fluorouracil, and leucovorin as adjuvant treatment for colon cancer. N Engl J Med 2004, 350(23):2343-51.

56. Langer B, Bleiberg H, Labianca R, Shepherd L, Nitti D, Marsoni S, Tu D, Sargeant AM, Fields A: Fluorouracil (FU) plus I-leucovorin (I-LV) versus observation after potentially curative resection of liver or lung metastases from colorectal cancer (CRC): results of the ENG (EORTC/ NCIC CTG/GIVIO) randomized trial Proc Am Soc Clin Oncol 21. 2002, (abstr 592).

57. Portier G, Elias D, Bouche O, Rougier P, Bosset JF, Saric J, Belghiti J, Piedbois P, Guimbaud R, Nordlinger B, Bugat R, Lazorthes F, Bedenne L: Multicenter randomized trial of adjuvant fluorouracil and folinic acid compared with surgery alone after resection of colorectal liver metastases: FFCD ACHBTH AURC 9002 trial. J Clin Oncol 2006, 24(31):4976-82.

58. Mitry E, Fields AL, Bleiberg H, Labianca R, Portier G, Tu D, Nitti D, Torri V, Elias D, O'Callaghan C, Langer B, Martignoni G, Bouché O, Lazorthes F, Van Cutsem E, Bedenne L, Moore MJ, Rougier P: Adjuvant chemotherapy after potentially curative resection of metastases from colorectal cancer: a pooled analysis of two randomized trials. J Clin Oncol 2008, 26(30):4906-11.

59. Ychou M, Hohenberger W, Thezenas S, Navarro M, Maurel J, Bokemeyer C, Shacham-Shmueli E, Rivera F, Kwok-Keung Choi C, Santoro A: A randomized phase III study comparing adjuvant 5 -fluorouracil/folinic acid with FOLFIRI in patients following complete resection of liver metastases from colorectal cancer. Ann Oncol 2009, 20(12):1964-70.

60. Voest EE, Snoeren N, Schouten SB, Bergman AM, van Werkhoven E, Loosveld OJL, van Gulik TM, Smit JM, Cats A, Boven E, Hesselink E, Rijken A, Tol M, Dalesio O, Verheul HM, Tollenaar RA, van der Sijp J, Borel Rinkes I, van Hillegersberg R: A randomized two-arm phase III study to investigate bevacizumab in combination with capecitabine plus oxaliplatin (CAPOX) versus CAPOX alone in post radical resection of patients with liver metastases of colorectal cancer. J Clin Oncol 2011, 29:2011, (suppl; abstr 3565)

61. Zorzi D, Laurent A, Pawlik TM, Lauwers GY, Vauthey JN, Abdalla EK: Chemotherapy-associated hepatotoxicity and surgery for colorectal liver metastases. Br J Surg 2007, 94(3):274-86.

62. Hübscher SG: Histological assessment of non-alcoholic fatty liver disease. Histopathology 2006, 49(5):450-65.

63. Cleary JM, Tanabe KT, Lauwers GY, Zhu AX: Hepatic toxicities associated with the use of preoperative systemic therapy in patients with metastatic colorectal adenocarcinoma to the liver. Oncologist 2009, 14(11):1095-105

64. Farrell GC, Larter CZ: Nonalcoholic fatty liver disease: from steatosis to cirrhosis. Hepatology 2006, 43(2 Suppl 1):S99-S112.

65. Ong JP, Younossi ZM: Epidemiology and natural history of NAFLD and NASH. Clin Liver Dis 2007, 11(1):1-16, vii.

66. Bellentani S, Saccoccio G, Masutti F, Crocè LS, Brandi G, Sasso F, Cristanini G, Tiribelli C: Prevalence of and risk factors for hepatic steatosis in Northern Italy. Ann Intern Med 2000, 132(2):112-7.

67. Kooby DA, Fong Y, Suriawinata A, Gonen M, Allen PJ, Klimstra DS, DeMatteo RP, D'Angelica M, Blumgart LH, Jarnagin WR: Impact of steatosis on perioperative outcome following hepatic resection. J Gastrointest Surg 2003, 7(8):1034-44.

68. Veteläinen R, van Vliet A, Gouma DJ, van Gulik TM: Steatosis as a risk factor in liver surgery. Ann Surg 2007, 245(1):20-30.

69. Vauthey JN, Pawlik TM, Ribero D, Wu TT, Zorzi D, Hoff PM, Xiong HQ, Eng C, Lauwers GY, Mino-Kenudson M, Risio M, Muratore A, Capussotti L, Curley SA, Abdalla EK: Chemotherapy regimen predicts steatohepatitis and an increase in 90-day mortality after surgery for hepatic colorectal metastases. J Clin Oncol 2006, 24(13):2065-72.

70. Helmy A: Review article: updates in the pathogenesis and therapy of hepatic sinusoidal obstruction syndrome. Aliment Pharmacol Ther 2006, 23(1):11-25.

71. Valla DC: Budd-Chiari syndrome and veno-occlusive disease/sinusoidal obstruction syndrome. Gut 2008, 7(10):1469-78.

72. Aloia T, Sebagh M, Plasse M, Karam V, Lévi F, Giacchetti S, Azoulay D, Bismuth $H$, Castaing D, Adam R: Liver histology and surgical outcomes after preoperative chemotherapy with fluorouracil plus oxaliplatin in colorectal cancer liver metastases. J Clin Oncol 2006, 24(31):4983-90.

73. Peppercorn PD, Reznek RH, Wilson P, Slevin ML, Gupta RK: Demonstration of hepatic steatosis by computerized tomography in patients receiving 5 -fluorouracil-based therapy for advanced colorectal cancer. Br J Cancer 1998, 77(11):2008-11.

74. Rubbia-Brandt L, Audard V, Sartoretti P, Roth AD, Brezault C, Le Charpentier M, Dousset B, Morel P, Soubrane O, Chaussade S, Mentha G Terris B: Severe hepatic sinusoidal obstruction associated with oxaliplatin-based chemotherapy in patients with metastatic colorectal cancer. Ann Oncol 2004, 15(3):460-6.

75. Fernandez FG, Ritter J, Goodwin JW, Linehan DC, Hawkins WG, Strasberg SM: Effect of steatohepatitis associated with irinotecan or oxaliplatin pretreatment on resectability of hepatic colorectal metastases. J Am Coll Surg 2005, 200(6):845-53.

76. Ellis LM, Curley SA, Grothey A: Surgical resection after downsizing of colorectal liver metastasis in the era of bevacizumab. J Clin Oncol 2005, 23(22):4853-5.

77. Natarajan A, Wagner B, Sibilia M: The EGF receptor is required for efficient liver regeneration. Proc Natl Acad Sci USA 2007, 104(43):17081-6.

78. Van Buren G 2nd, Yang AD, Dallas NA, Gray MJ, Lim SJ, Xia L, Fan F, Somcio R, Wu Y, Hicklin DJ, Ellis LM: Effect of molecular therapeutics on liver regeneration in a murine model. $J$ Clin Oncol 2008, 26(11):1836-42.

79. Karoui M, Penna C, Amin-Hashem M, Mitry E, Benoist S, Franc B, Rougier P, Nordlinger $B$ : Influence of preoperative chemotherapy on the risk of major hepatectomy for colorectal liver metastases. Ann Surg 2006, 243(1):1-7.

80. Nordlinger B, Van Cutsem E, Gruenberger T, Glimelius B, Poston G, Rougier P, Sobrero A, Ychou M, European Colorectal Metastases Treatment Group: Combination of surgery and chemotherapy and the role of targeted agents in the treatment of patients with colorectal liver metastases: recommendations from an expert panel. Sixth International Colorectal Liver Metastases Workshop. Ann Oncol 2009, 20(6):985-92. 
doi:10.1186/1477-7819-9-154

Cite this article as: Ismaili: Treatment of colorectal liver metastases.

World Journal of Surgical Oncology 2011 9:154.

Submit your next manuscript to BioMed Central and take full advantage of:

- Convenient online submission

- Thorough peer review

- No space constraints or color figure charges

- Immediate publication on acceptance

- Inclusion in PubMed, CAS, Scopus and Google Scholar

- Research which is freely available for redistribution

Submit your manuscript at 